\title{
Synthesis of Novel Poly(amido ethylenimine) (PAMEIM) Dendrimer and Its Self-assembly with Plasmid DNA
}

\author{
Tae-il Kim, Jung-un Baek, Cheng Zhe Bai, and Jong-sang Park ${ }^{*}$ \\ School of Chemistry \& Molecular Engineering, Seoul National University, Seoul 151-742, Korea \\ "E-mail: pfjspark@plaza.snuackr. \\ Received September 4, 2006
}

Key Words : Gene delivery carrier, Dendrimer, Self-assembly

A lot of non-viral gene delivery carriers including cationic lipids and polymers have been developed due to their advantages such as easy introduction of specific bio-functionalities, convenient handling, non-immunogenicity and unlimited capacity of genes delivered. ${ }^{1,2}$

Poly(ethylenimine) (PEI) and poly(amido amine) (PAMAM) dendrimer are representative and commercialized polymeric gene delivery carriers. ${ }^{3 .-}$ PEI shows very high transfection efficiency caused by its 'endosome buffering' capacity' but its severe cytotoxicity limited its application for gene delivery and led its chemical modification for reducing the cytotoxicity. ${ }^{6}$ Recently, interesting strategies based on the preincubation of potent glucocorticoid, dexamethasone before transfection and the conjugation of mitochondrial leader peptide to PEI have been also tried in order to enhance the transfection efficiency of PEI by glucocorticoid ligand-receptor interaction and to perform selective delivery of genes to mitochondria, respectively. ${ }^{7.8}$

The transfection efficiency of PAMAM dendrimer is lower than that of PEI. However, its controllable multivalent functionality, defined structure and biocompatibility is still arising many scientists' interest for gene delivery systems. So, we intended to design a novel hybrid dendrimer, poly(amido ethylenimine) (PAMEIM) dendrimer possessing the endosome buffering capacity of PEI and the defined structure, biocompatibility of PAMAM dendrimer in order to combine their advantages.

Here, we report synthesis of a novel PAMEIM dendrimer and characterization of its self-assembly with plasmid DNA in order to identify its potential as a gene delivery carrier.

\section{Experimental Section}

Materials. Ammonia, methyl acrylate, ethylenediamine, 2-aminoethyl hydrogen sulfate, benzlychloroformate, anhydrous $t=\mathrm{BuOH}$, and $\mathrm{Pd} / \mathrm{C}(10 \%$, activated carbon) were purchased from Sigma-Aldrich (St. Louis, MO). All chemicals were used without any other purification.

Synthesis.

Synthesis of PAMAM G -0.5. Ammonia and 100 equiv. of methyl acrylate (MA) were dissolved in methanol, respectively. Ammonia solution was added to MA solution dropwise. Reaction mixture was stirred in $37^{\circ} \mathrm{C}$ for 2 days. After reaction, solvent was removed by rotary evaporator and residual product was stored in vacuum.

Synthesis of PAMAM G 0. PAMAM G -0.5 and 100 equiv. of ethylenediamine (EDA) was dissolved in methanol, respectively. PAMAM solution was added to EDA solution and stirred in $50^{\circ} \mathrm{C}$ for 2 days. After reaction, solvent was removed by rotary evaporator. Residual product was precipitated in ethyl ether by 2 times and stored in vacuum.

Synthesis of Cbz-aziridine. Cbz-aziridine was synthesized according to previous report ${ }^{9}$ and shown in Scheme 2. Briefly, 2-aminoethyl hydrogen sulfate and $40 \% \mathrm{NaOH}$ solution was distilled for $2 \mathrm{~h}$ at $100-120^{\circ} \mathrm{C}$ under atmosphere. After determination of content of aziridine in distillate by 'H NMR, aziridine solution was saturated with $\mathrm{KOH}$. Benzlychloroformate/ethyl ether solution was added to the aqueous aziridine dropwise with vigorous stirring for $2 \mathrm{~h}$ at 0 ${ }^{\circ} \mathrm{C}$. The reaction mixture was extracted with ethyl ether and purified by silica column chromatography (ethyl acetate : hexane $=1: 5$ ).

Synthesis of Dendrimer 1-6C bz. PAMAM G 0 and 2.4 equiv. of Cbz-aziridine were dissolved in anhydrous $t$ $\mathrm{BuOH}$, respectively. They were mixed and refluxed at $70^{\circ} \mathrm{C}$ for 7 days under $\mathrm{N}_{2}$. After cooling to room temperature, reaction mixture was precipitated by $\mathrm{HCl} /$ ethyl ether solution. After basification of the precipitate by $\mathrm{NaOH}$ solution, product was extracted with $\mathrm{CHCl}_{3}$. Solvent was removed by evaporation, leaving a sticky yellow oil, Dendrimer 1-6Cbz.

Synthesis of Dendrimer 1. Cbz groups of the dendrimer 1 were removed by hydrogenolysis with $\mathrm{Pd} / \mathrm{C}(10 \%$, activated carbon) in $\mathrm{MeOH}$ for $4 \mathrm{~h}$ at room temperature. Reaction mixture was filtered and solvent was evaporated.

Synthesis of Dendrimer 2. Dendrimer 1 and 100 equiv. of MA was dissolved in methanol. PAMEIM G 1 solution was added to MA solution dropwise. Reaction mixture was stirred in $37^{\circ} \mathrm{C}$ for 2 days. After reaction, the reaction mixture was precipitated with ethyl ether 2 times and product was stored in vacuum.

Synthesis of PAMEIM dendrimer. Dendrimer 2 and 200 equiv. of EDA was dissolved in methanol, respectively. PAMEIM solution was added to EDA solution and stirred in $50{ }^{\circ} \mathrm{C}$ for 2 days. After reaction, reaction mixture was precipitated with ethyl ether 2 times and dialyzed against ultra-pure water in dialysis membrane $(\mathrm{MWCO}=1000)$. 


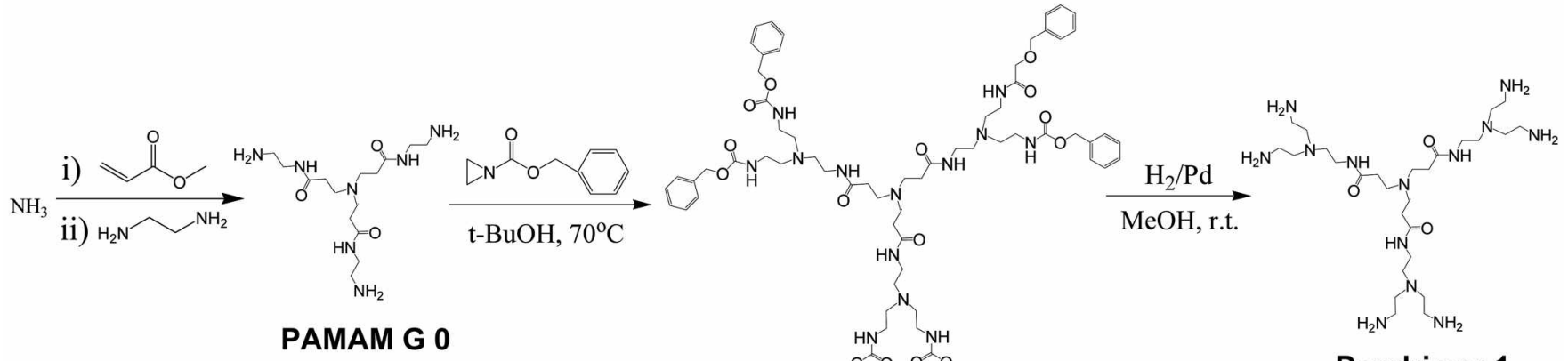

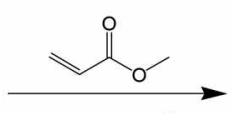

$\mathrm{MeOH}, 37^{\circ} \mathrm{C}$

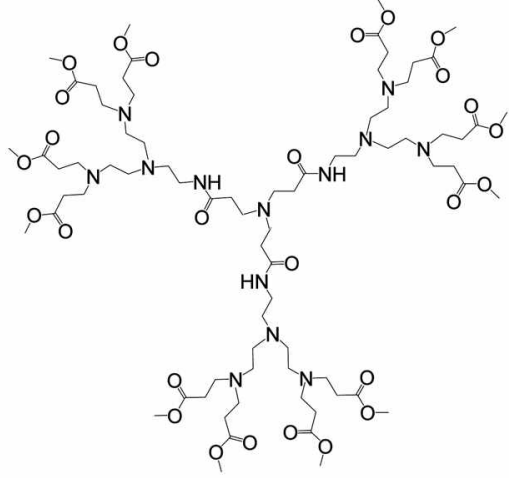

Dendrimer 2

\section{Dendrimer $1-6 \mathrm{Cbz}$}

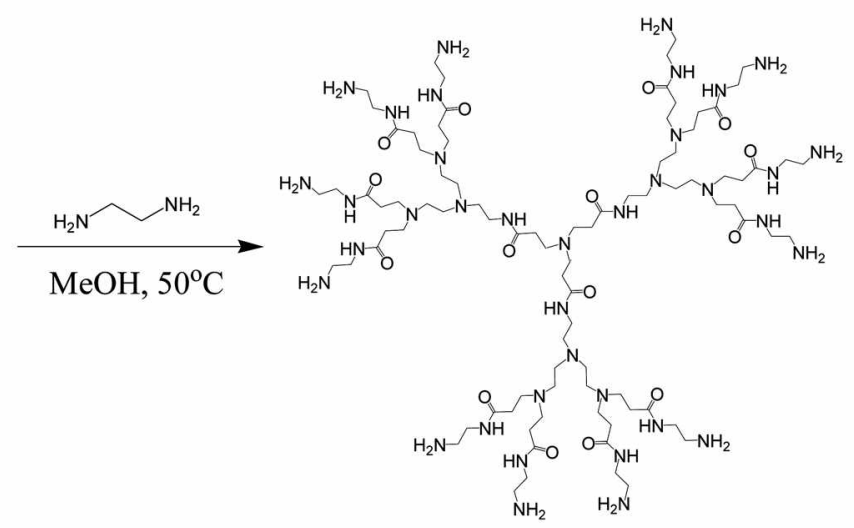

PAMEIM

Scheme 1. Synthetic scheme of PAMEIM dendrimer.

Agarose gel retardation assay. PAMEIM polyplexes at various charge ratios ranging from 0.5 to 5 , were prepared in Hepes buffered saline ( $10 \mathrm{mM}$ Hepes, $1 \mathrm{mM} \mathrm{NaCl}$, pH 7.4). After $30 \mathrm{~min}$ incubation at room temperature, the samples were electrophoresed on a $0.7 \%(\mathrm{w} / \mathrm{v})$ agarose gel and stained in an ethidium bromide solution $(0.5 \mu \mathrm{g} / \mathrm{mL})$, and analyzed on a UV illuminator to show the location of the DNA.

Average size measurements of the polyplex. $2 \mathrm{~mL}$ of polyplex solutions containing $1 \mu \mathrm{g}$ of DNA were prepared at various charge ratios ranging from 1 to 10 . After $30 \mathrm{~min}$ incubation, polyplex sizes were measured using a Zetasizer $3000 \mathrm{HS}(5 \mathrm{~mW}$ HeNe laser, $633 \mathrm{~nm}$, Malvem Instruments, UK) at $25^{\circ} \mathrm{C}$.

Zeta-potential measurements of the polyplex. $2 \mathrm{~mL}$ of polyplex solution containing $1 \mu \mathrm{g}$ of DNA were prepared in Hepes buffered saline at various charge ratios ranging from 1 to 10 . After $30 \mathrm{~min}$ incubation, each polyplex solution was diluted to a $10 \mathrm{~mL}$ final volume prior to measurements. Zeta-potential measurements were carried out using a Zetasizer $3000 \mathrm{HS}$ at $25^{\circ} \mathrm{C}$.

\section{Results and Discussion}

The synthesis of PAMEIM dendrimer began from PAMAM dendrimer core and the dendrimer stretched out by traditional PAMAM branch extension reaction (Michae] addition and exhaustive amidation) as shown in Scheme I. Intemal

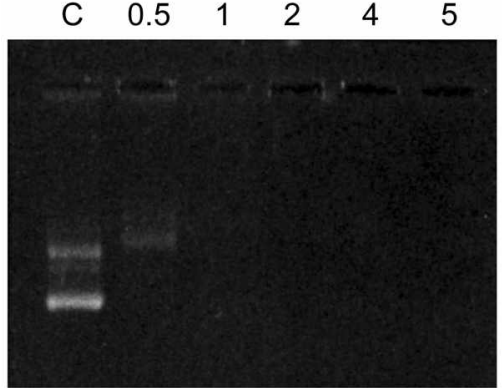

Figure 1. Gel retardation assay of PAMEIM polyplex.

tertiary amines for the endosome buffering capacity were introduced by ring opening reaction of Cbz-aziridine. Each synthesis step was confirmed by ${ }^{1} \mathrm{H}$ NMR $(300 \mathrm{MHz}$, Bruker DPX-300) as follows.

Synthesis of PAMAM G -0.5. 'H NMR (MeOD): $\delta$ $\left(-\mathrm{NCH}_{2} \mathrm{CH}_{2} \mathrm{CO}-\right)=2.44 ; \delta\left(-\mathrm{NCH}_{2} \mathrm{CH}_{2} \mathrm{CO}-\right)=2.73 ; \delta$ $\left(-\mathrm{NCH}_{2} \mathrm{CH}_{2} \mathrm{COCH}_{3}\right)=3.65$.

Synthesis of PAMAM G 0. 'H NMR $\left(\mathrm{D}_{2} \mathrm{O}\right): \delta\left(-\mathrm{NCH}_{2}-\right.$ $\left.\mathbf{C H}_{2} \mathrm{CO}-\right)=2.45 ; \delta\left(-\mathrm{NCH}_{2} \mathrm{CH}_{2} \mathrm{CO}-\right)=2.73 ; \delta$ core $\left(-\mathrm{CONHCH}_{2} \mathrm{CH}_{2} \mathrm{NH}_{2}\right)=2.82 ; \delta\left(-\mathrm{CONHCH}_{2} \mathrm{CH}_{2} \mathrm{NH}_{2}\right)=$ 3.25 .

Synthesis of Cbz-aziridine. ' $\mathrm{H}$ NMR $\left(\mathrm{CDCl}_{3}\right)$ : $\delta$ aziridine $\left(-\mathrm{CH}_{2} \mathrm{CH}_{2-}\right)=2.27 ; \delta\left(-\mathrm{OCH}_{2} \mathrm{Ph}\right)=5.14 ; \delta\left(-\mathrm{OCH}_{2} \mathrm{Ph}\right)$ $=7.36$.

Synthesis of Dendrimer 1-6Cbz. ${ }^{1} \mathrm{H}$ NMR $\left(\mathrm{CDCl}_{3}\right): \delta$ $\left(-\mathrm{NCH}_{2} \mathbf{C H}_{2} \mathrm{CO}-\right)=2.14 ; \delta$ (protons next to tertiary amine $)=$ 


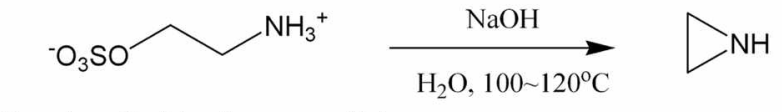

2-aminoethyl hydrogen sulfate

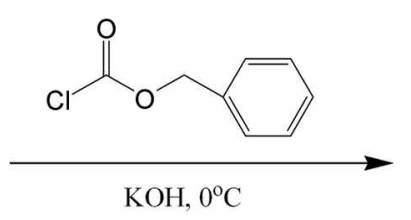

$\mathrm{KOH}, 0^{\circ} \mathrm{C}$

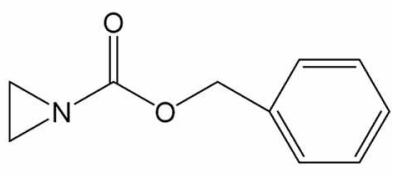

Cbz-aziridine

Scheme 2. Synthetic scheme of Cbz-aziridine.

Table 1. Number average sizes and zeta-potentials of PAMEIM polyplexes. Numbers of topside row represent charge ratios. All values were represented as the average values of 5 runs

\begin{tabular}{cccccc}
\hline & DNA & $\mathbf{1}$ & $\mathbf{2}$ & $\mathbf{4}$ & $\mathbf{1 0}$ \\
\hline Size $(\mathrm{nm})$ & - & $76.4 \pm 39.0$ & $83.4 \pm 35.3$ & $54.6 \pm 30.3$ & $52.5 \pm 29.6$ \\
Zeta-potential $(\mathrm{mV})$ & $-40.1 \pm 18.6$ & $3.9 \pm 1.8$ & $3.2 \pm 0.4$ & $22.9 \pm 4.3$ & $14.8 \pm 10.1$ \\
\hline
\end{tabular}

$2.52 ; \delta\left(-\mathrm{CONHCH}_{2} \mathrm{CH}_{2} \mathrm{~N}-,-\mathrm{NCH}_{2} \mathrm{CH}_{2} \mathrm{NCOOCH}_{2} \mathrm{Ph}\right)=$ $3.21 ; \delta\left(-\mathrm{NCH}_{2} \mathrm{CH}_{2} \mathrm{NCOOCH}_{2} \mathrm{Ph}\right)=5.02 ; \delta\left(-\mathrm{NCH}_{2} \mathrm{CH}_{2} \mathrm{~N}-\right.$ $\left.\mathrm{COOCH}_{2} \mathrm{Ph}\right)=7.26$.

Synthesis of Dendrimer 1. 'H NMR $\left(\mathrm{D}_{2} \mathrm{O}\right): \delta\left(-\mathrm{NCH}_{2}-\right.$ $\mathbf{C H}_{2} \mathrm{CO}-$ ) $=2.44 ; \delta$ (protons next to tertiary and primary amine $)=2.70-2.97 ; \delta\left(-\mathrm{CONHCH}_{2} \mathrm{CH}_{2} \mathrm{NH}_{2}\right)=3.30$.

Synthesis of Dendrimer 2. 'H NMR (MeOD): $\delta\left(-\mathrm{NCH}_{2}-\right.$ $\left.\mathbf{C H}_{2} \mathrm{CO}-\right)=2.39 ; \delta\left(-\mathrm{NCH}_{2} \mathbf{C H}_{2} \mathrm{COOH}_{3}\right)=2.46 ; \delta$ (protons next to tertiary and primary amine $)=2.68-2.95 ; \delta(-\mathrm{CONH}-$ $\left.\mathrm{CH}_{2} \mathrm{CH}_{2} \mathrm{NH}_{2}\right)=3.25 ; \delta\left(-\mathrm{NCH}_{2} \mathrm{CH}_{2} \mathrm{COCH}_{3}\right)=3.30$.

Synthesis of PAMEIM dendrimer. 'H NMR $\left(\mathrm{D}_{2} \mathrm{O}\right): \delta$ $\left(-\mathrm{NCH}_{2} \mathrm{CH}_{2} \mathrm{CO}-\right)=2.48 ; \delta$ (protons next to tertiary and primary amine $)=2.67-3.00 ; \delta\left(-\mathrm{CONHCH}_{2} \mathrm{CH}_{2}-\right)=3.42$.

Then, we perfomed agarose gel retardation assay of PAMEIM dendrimer in order to identify the self-assembly with plasmid DNA (pCN-Luci ${ }^{10}$ ). As shown in Figure 1, PAMEIM dendrimer could retard plasmid DNA at a charge ratio of $I$ and showed good DNA condensing ability. In order to inspect the physical properties of the polyplex, we also examined the number average sizes and zeta-potentials of PAMEIM polyplexes at various charge ratios ranging from 1 to 10 by using Zetasizer. Table 1 shows the result. PAMEIM dendrimer was found to form nano-sized particles with plasmid DNA with diameters less than $100 \mathrm{~nm}$. It means that self-assembly of PAMEIM dendrimer with plasmid DNA leads the formation of compactly condensed nano-particles with size proper to efficient gene delivery. " The zeta-potentials of PAMEIM polyplex were about $3 \mathrm{mV}$ at low charge ratios (1-2) but increased to $15-20 \mathrm{mV}$ at high charge ratios (5-10). Positive charge of PAMEIM polyplexes is thought to induce the spontaneous adsorption of polyplexes to negatively charged cellular membrane, prior to cellular internalization. ${ }^{12}$

In conclusion, a novel PAMEIM dendrimer was synthe- sized, and able to self-assemble with plasmid DNA and to form nano-sized and positively charged polyplex particles. This result represents its potential for gene delivery systems. Further experiments including cytotoxicity measurement and transfection experiment of PAMEIM dendrimer are in progress.

Acknowledgments. This work was supported by the Korea Health 21 R\&D Project of The Ministry of Health \& Welfare, Republic of Korea (A04-0004), and the Gene Therapy Project of The Ministry of Science and Technology (M1053403004-05N3403-00410).

\section{References and Notes}

I. Luo, D.; Saltzman, W. M. Nat, Biotechol. 2000, $18,33$.

2. Kim, T.-i.; Seo, H. J.; Choi, J. S.; Jang, H.-S.; Baek, J.-u.; Kim, K.; Park, J.-S. Biomacromolecules 2004, 5, 2487.

3. Boussif, O.; Lezoualc'h, F.; Zanta, M. A.; Mergny, M. D.; Scherman, D.; Demeneix. B.; Behr, J.-P. Proc. Nat. Acad. Sci. U. S. A. $1995,92,7297$.

4. Haensler, J.; Szoka, F, C. Jr. Bioconingate Chem, 1993, 4, 372.

5. Godbey, W. T.; Wu, K. K.; Mikos, A. G J. Control. Release 1999, 60,149 .

6. Forrest, M. L.; Koerber, J. T.; Pack, D. W. Bioconingate Chen. 2003. 14.934.

7. Choi, J. S.; Lee, M. Bull. Korean Chent. Soc. 2005, 26, 1209.

8. Choi, J. S.; Choi, M. J.; Ko, K. S.; Rhee, B. D.; Kim Pak, Y.; Bang, I. S.; Lee, M. Bull. Korean Chem. Soc. 2006, 27, 1335.

9. Lee, S. H.; Kim, D.-j.; Chang, C.-c; Hah, S. S.; Suh, J. Bull. Korean Chem. Soc. 1998. 19. 1270.

10. Lee, M. J.; Cho, S. S.; You, J. R.; Lee, Y.; Kang, B. D.; Choi, J. S.; Park, J. W.; Suh, Y. L.; Kim, J. A.; Kim, D. K.; Park, J. S. Gene Ther, 2002, 9, 859.

11. Zauner, W; Ogris, M.; Wagner, E. Adv, Drug. Deliv, Rev: 1998, 30,97 .

12. Kabanov, A. V.; Kabanov, V. A. Bioconitigate Chem. 1995, 6, 7. 